\title{
Sporomusa silvacetica sp. nov., an Acetogenic Bacterium Isolated from Aggregated Forest Soil
}

\author{
CARLA H. KUHNER, ${ }^{1}$ CLAUDIA FRANK, ${ }^{1}$ ANJA GRIEßHAMMER, ${ }^{1}$ MARTINA SCHMITTROTH, \\ GEORG ACKER, ${ }^{2}$ ANITA GÖBNER, ${ }^{1}$ AND HAROLD L. DRAKE ${ }^{1 *}$ \\ Lehrstuhl für Ökologische Mikrobiologie, BITÖK, ${ }^{1}$ and Biologie, Elektron Mikroskopie, ${ }^{2}$ \\ Universität Bayreuth, 95440 Bayreuth, Germany
}

\begin{abstract}
Sporomusa silvacetica sp. nov. DG-1 ${ }^{\mathrm{T}}$ (= DSMZ $\left.10669^{\mathrm{T}}\right)(\mathrm{T}=$ type strain) was isolated from well-drained, aggregated forest soil ( $\mathrm{pH} \mathrm{6.0)}$ in east-central Germany. The cells were obligately anaerobic, slightly curved rods and were motile by means of laterally inserted flagella on the concave side of each cell. Typical cells were approximately 3.5 by $0.7 \mu \mathrm{m}$. Cells stained weakly gram positive, but thin sections revealed a complex multilayer cell wall. Spores were spherical and distended the sporangia. Growth and substrate utilization occurred with ferulate, vanillate, fructose, betaine, fumarate, 2,3-butanediol, pyruvate, lactate, glycerol, ethanol, methanol, formate, and $\mathrm{H}_{2}-\mathrm{CO}_{2}$. With most substrates, acetate was the primary reduced end product and was produced in stoichiometries indicative of an acetyl-coenzyme A pathway-dependent metabolism. Fumarate was dismutated to succinate and acetate. Methoxyl and acrylate groups of various aromatic compounds were O-demethylated and reduced, respectively. Yeast extract was not required for growth. Cells grew optimally at approximately $30^{\circ} \mathrm{C}$ and $\mathrm{pH} \mathrm{6.8}$; under these conditions and with fructose as the substrate, the doubling time was approximately $14 \mathrm{~h}$. The lowest temperature that supported growth was between 5 and $10^{\circ} \mathrm{C}$. The carbon monoxide dehydrogenase and hydrogenase activities were approximately 9 and $102 \mu \mathrm{mol} \mathrm{min}{ }^{-1} \mathrm{mg}_{\text {of pro- }}$ tein $^{-1}$, respectively. A type $b$ cytochrome was detected in the membrane. The $G+C$ content was approximately $43 \mathrm{~mol} \%$. Phylogenetic analysis of the $16 \mathrm{~S}$ ribosomal DNA indicated that DG-1 ${ }^{\mathrm{T}}$ was most closely related to members of the genus Sporomusa in the Clostridium subphylum of the gram-positive bacteria.
\end{abstract}

Low-molecular-weight aliphatic organic acids are present in mineral forest soil solutions and are believed to play roles in soil formation, solubility of toxic metals, and plant growth $(23$, $24,30,49,58,59)$. In this regard, acetate is a dominate organic acid detected in mineral soils (59), and it has been proposed that the acetate in mineral soils is produced primarily through the collective action of facultatively and obligately anaerobic microorganisms $(35,63)$. Although well-drained soils are not considered typical acetogenic habitats, supplementation of forest $(34,35)$, prairie $(63)$, and tundra (46) soils with $\mathrm{H}_{2}$ or $\mathrm{CO}$ results in the utilization of substrates and the production of acetate in stoichiometries approximating those expected for $\mathrm{H}_{2}-$ or $\mathrm{CO}-$ dependent acetogenesis. In addition, acetogenic consortia are readily enriched from mineral forest soils $(35,48)$ and leaf litter (36). To further evaluate the occurrence of acetogens in well-drained, aggregated soils, an acetogen was isolated from a beech forest in east-central Germany. The collective characteristics of this isolate (strain DG- $1^{\mathrm{T}}[\mathrm{T}=$ type strain]) are not consistent with the characteristics of any previously described acetogenic bacterium, and it is proposed that this organism should be placed in a new species, Sporomusa silvacetica.

\section{MATERIALS AND METHODS}

Soil collection. Forest soil (a silty loam) was obtained from the mineral (Ah) horizon of a slightly acidic beech site in the Geisberger Forest in east-central Germany. The soil had a pH of approximately 6 , a dry weight of $60 \%$, and an organic carbon content of $80 \mathrm{~g} \mathrm{~kg}^{-1}$ (dry weight) (see reference 35 for additional site and soil characteristics). The soil was collected in sterile glass containers and was utilized immediately after transportation to the laboratory.

Enrichment cultures. Soil samples were placed in an anaerobic chamber $\left(100 \% \mathrm{~N}_{2}\right.$ gas phase; room temperature; Mecaplex, Grenchen, Switzerland) and added to anaerobic medium (approximately $1 \mathrm{~g}$ [wet weight] of soil per $10 \mathrm{ml}$ of medium). The medium was then supplemented with either $\mathrm{H}_{2}-\mathrm{CO}_{2}(80: 20)$ or a

* Corresponding author. Phone: (49)-(0)921-555-640. Fax: (49)(0)921-555-799. E-mail: harold.drake@bitoek.uni-bayreuth.de. combination of vanillate $(5 \mathrm{mM})$ and $\mathrm{CO}(100 \%)$ (the gas volumes were $20 \mathrm{ml}$ per $120-\mathrm{ml}$ vial or $10 \mathrm{ml}$ per $30-\mathrm{ml}$ vial). Enrichment cultures were incubated at $15^{\circ} \mathrm{C}$, and stable enrichment cultures were obtained by repeated transfer in the same medium. After several transfers, enrichment cultures were streaked onto solid media (media supplemented with $1.5 \%$ agar). Isolated colonies were transferred to liquid media and assayed for substrate utilization and product formation

Composition of media and growth conditions. Media were prepared anaerobically (31). Medium A was an undefined, carbonate-buffered medium (16) Medium $B$ was medium A without yeast extract or resazurin. These media were dispensed under $\mathrm{CO}_{2}$ into $120-\mathrm{ml}$ serum vials $(50 \mathrm{ml}$ of medium per vial) or $27-\mathrm{ml}$ culture tubes ( $7 \mathrm{ml}$ of medium per tube), which were then crimp sealed and autoclaved. Medium $\mathrm{C}$ was a defined, carbonate-buffered medium containing trace element solution SL10 $(64,65)$. This medium was adjusted to $\mathrm{pH} 6.5$ prio to autoclaving, and an alternative vitamin solution (67) was utilized $(1 \mathrm{ml} \mathrm{li}$ $\left.\operatorname{ter}^{-1}\right)$; after autoclaving, the medium was dispensed under $\mathrm{N}_{2}-\mathrm{CO}_{2}(90: 10)$. Lea leachate medium was prepared by incubating leaves $(500 \mathrm{~g})$ from the litter laye at Geisberg, Germany, in distilled water $(750 \mathrm{ml})$ for 1 week at $20^{\circ} \mathrm{C}$. The liquid was then decanted, centrifuged $(10,000 \times \mathrm{g}, 20 \mathrm{~min})$, filter sterilized, and made anoxic by gassing with $100 \%$ argon. The leaf leachate $(\mathrm{pH} 5.9)$ was diluted $1: 1$ with distilled water and was added to sterile $30-\mathrm{ml}$ serum vials $(10 \mathrm{ml}$ per vial) under $100 \%$ argon. Soil extract medium was prepared by adding $20 \mathrm{~g}$ of soil to $75 \mathrm{ml}$ of deionized, anoxic water. The resulting soil suspensions were placed on an end-over-end shaker $\left(40\right.$ cycles $\left.\min ^{-1}\right)$ for $2 \mathrm{~h}$ at $4^{\circ} \mathrm{C}$. The aqueous phase was then centrifuged $(10,000 \times \mathrm{g}, 20 \mathrm{~min})$, filter sterilized, and gassed with and dispensed under $100 \%$ argon.

The reduction of sulfate was determined by using a sulfate-enriched lactate medium (50) supplemented with $0.1 \mathrm{~g}$ of cysteine $\cdot \mathrm{HCl}$ liter $^{-1}$; tubes were visually inspected for sulfide production (i.e., blackening of the precipitate). The reduction of nitrate was determined by using medium A supplemented with 5 $\mathrm{mM} \mathrm{KNO}$. The fixation of $\mathrm{N}_{2}$ was determined by using a medium designed to assess $\mathrm{N}_{2}$-fixing microorganisms (52); a trace element solution (1) (1 ml liter $\left.{ }^{-1}\right)$ replaced yeast extract, and the medium was prepared with a $100 \% \mathrm{~N}_{2}$ gas phase. Unless otherwise indicated, the temperature of incubation was $25^{\circ} \mathrm{C}$

Transmission electron microscopy. Cells were cultivated at $30^{\circ} \mathrm{C}$ in medium A supplemented with $10 \mathrm{mM}$ fructose and harvested by centrifugation. The cells were negatively stained with uranyl acetate (62). For thin-section preparations, cells were fixed in glutaraldehyde- $\mathrm{OsO}_{4}$ and prepared by a standard protocol (60). Thin sections were stained with uranyl acetate and lead acetate (53) Specimens were observed with a model CEM 902A microscope (Zeiss, Oberkochen, Germany)

Preparation of cell extract and enzyme assays. Cells were cultivated in medium A supplemented with $5 \mathrm{mM}$ fructose. Cultures (total volume, 1.3 liters were dispensed into centrifuge bottles in a Mecaplex anaerobic chamber $(100 \%$ $\mathrm{N}_{2}$ gas phase; room temperature) and centrifuged $\left(10,000 \times \mathrm{g}, 20 \mathrm{~min}, 4^{\circ} \mathrm{C}\right)$. The 

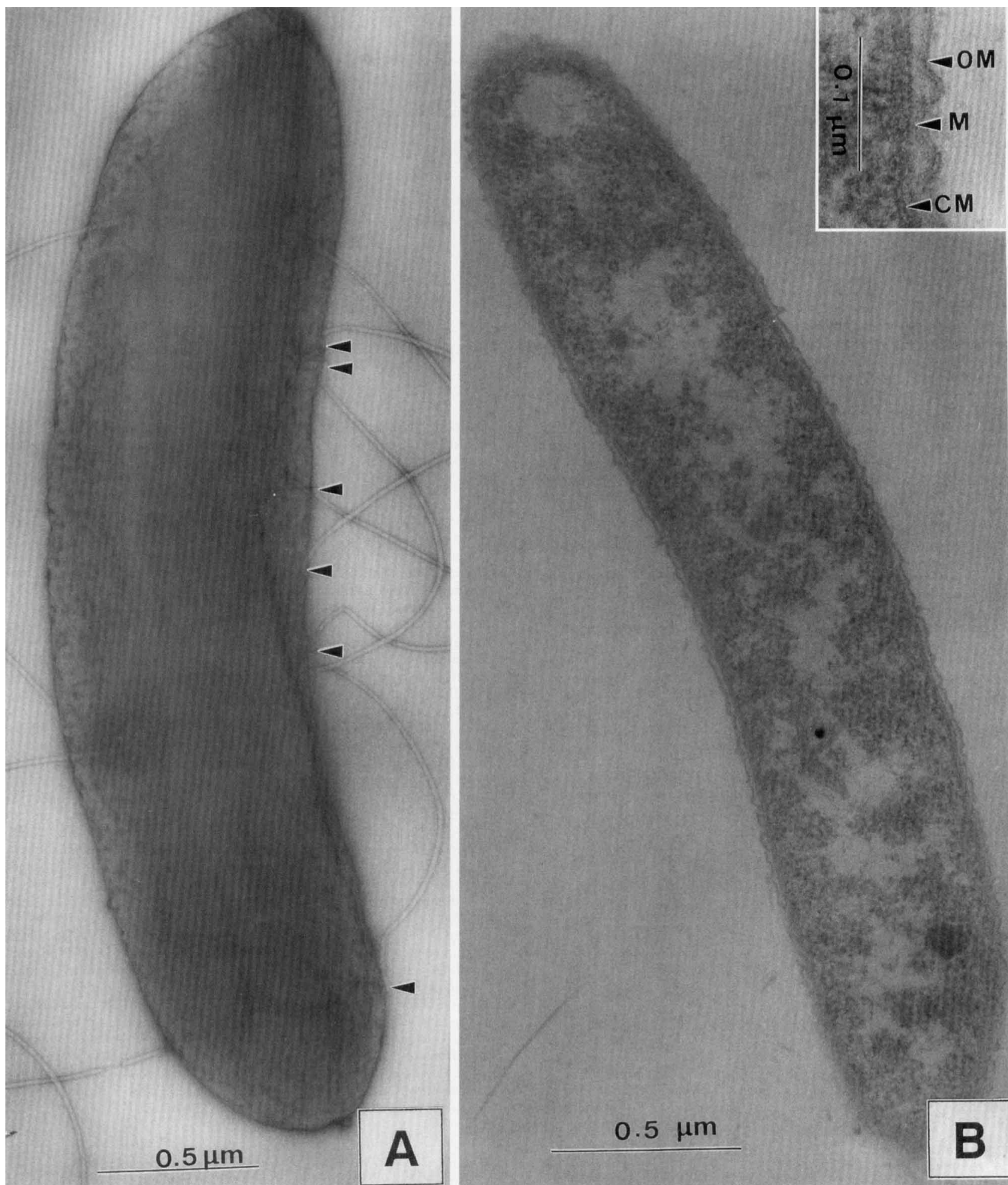


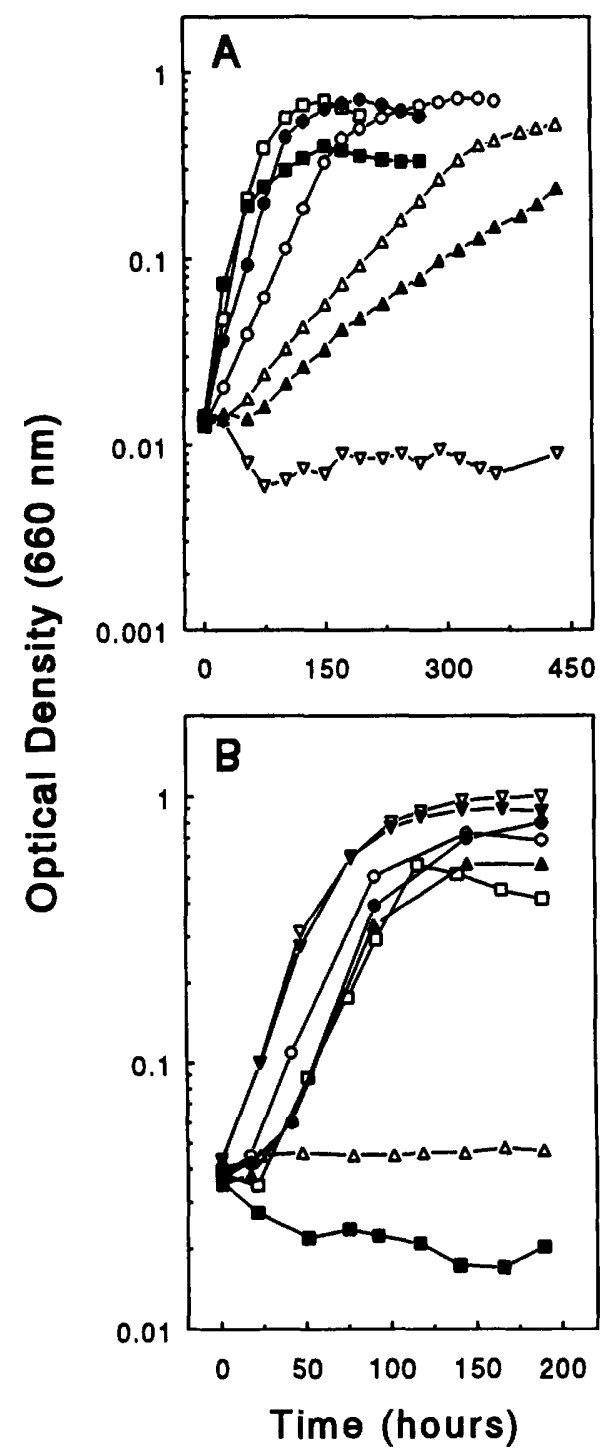

FIG. 2. Effect of temperature (A) and $\mathrm{pH}(\mathrm{B})$ on the growth of strain DG-1 ${ }^{\mathrm{T}}$ in medium $\mathrm{A}$ (unless otherwise indicated) supplemented with $10 \mathrm{mM}$ fructose. (A) The temperatures tested were $10^{\circ} \mathrm{C}(\Delta), 15^{\circ} \mathrm{C}(\triangle), 20^{\circ} \mathrm{C}(\mathrm{O}), 25^{\circ} \mathrm{C}(\bullet), 30^{\circ} \mathrm{C}$ $(\square), 35^{\circ} \mathrm{C}(\square)$, and 5 or $42^{\circ} \mathrm{C}(\nabla)$. (B) The initial pHs were pH 4.6 (tryptic soy broth $\left.\left[3 \mathrm{~g} \mathrm{liter}^{-1}\right]\right)(\triangle), \mathrm{pH} 5.5(\mathbf{\Delta}), \mathrm{pH} 5.9(\bullet), \mathrm{pH} 6.2(\bigcirc), \mathrm{pH} 6.8(\nabla), \mathrm{pH} 7.2$ $(\boldsymbol{\nabla}), \mathrm{pH} 7.7(\square)$, and $\mathrm{pH} 8.0(\mathbf{\square})$.

dehydrogenase activity was performed at room temperature. Reduction of acetylene was used to evaluate nitrogenase activity (37).

Membrane preparation and redox difference spectra. Cells were cultivated in medium A supplemented with $10 \mathrm{mM}$ fructose. Membranes were prepared from cell extracts by ultracentrifugation under aerobic conditions (26). Washed mem-

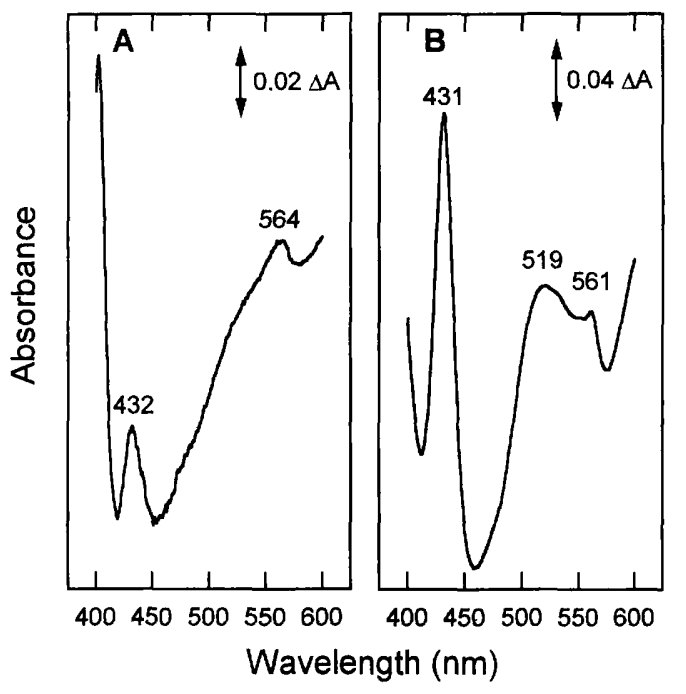

FIG. 3. Redox difference spectra for strain DG-1 ${ }^{\mathrm{T}}$ membranes (A) and cytoplasm (B). The protein concentrations used for the spectra shown in panels $A$ and $B$ were 1.4 and $11.2 \mathrm{mg} \mathrm{ml}^{-1}$, respectively.

branes were reduced with sodium dithionite, and reduced-minus-oxidized spectra were obtained with a model Uvikon 930 double-beam recording spectrophotometer (Kontron Instruments, Milan, Italy) at room temperature (26).

$\mathrm{G}+\mathrm{C}$ content. Cells were washed with phosphate buffer $(50 \mathrm{mM}, \mathrm{pH} 7.0$ ), and DNA was extracted by the $\mathrm{NaOH}$ method (3). The $\mathrm{G}+\mathrm{C}$ content was determined by high-performance liquid chromatography (42).

Analysis of 16S rDNA. Approximately $95 \%$ of the 16S rRNA gene (rDNA) sequence of strain DG- $1^{\mathrm{T}}$ was determined by directly sequencing PCR-amplified 16S rDNA. The analysis was performed by workers at the Deutsche Sammlung von Mikroorganismen und Zellkulturen, Braunschweig, Germany. Genomic DNA extraction, PCR-mediated amplification of the $16 \mathrm{~S}$ rDNA, and purification of the PCR products were performed by using previously described protocols (51). Purified PCR products were sequenced by using an ABI PRISM Ready Reaction dye terminator cycle sequencing kit (Applied Biosystems, Foster City, Calif.). Sequence reaction mixtures were electrophoresed with an Applied Biosystems model 373A DNA sequencer. The sequence data were put into alignment editor ae2 (40), aligned manually, and compared with available 16S rDNA sequences of representative organisms belonging to the Clostridium subphylum of the gram-positive bacteria. A dendrogram was constructed by using standard phylogenetic methods and the PHYLIP package $(22,32,54)$

Additional analytical methods. Growth and cell dry weight were determined as previously described (16). For fructose-containing cultures, a culture optical density at $660 \mathrm{~nm}$ of 1 corresponded to $133 \mathrm{mg}$ (dry weight) of cells liter ${ }^{-1}$ Protein content was determined by the Bradford method (6). The amounts of substrates and products present in culture fluids and gas phases were determined by high-performance liquid chromatography and gas chromatography $(16,27,35$, 41). Soil pH was determined by using $1: 2.5$ suspensions of soil in $0.02 \mathrm{~N} \mathrm{CaCl}_{2}$, and soil dry weight was obtained by weighing samples before and after drying at $105^{\circ} \mathrm{C}$ for $16 \mathrm{~h}$. The amount of total carbon in oven-dried $\left(65^{\circ} \mathrm{C}\right)$, homogenized organic matter was determined with an element analyzer (CHN-O-Rapid instrument; Foss-Heraeus, Hanau, Germany). The nitrate content was determined colorimetrically (11). The results and values given below are representative of the results and values obtained in duplicate experiments.

TABLE 1. Substrate-product stoichiometries for strain DG-1 $1^{\mathrm{T}}$ grown in medium A at $25^{\circ} \mathrm{C}$

\begin{tabular}{|c|c|c|c|c|c|}
\hline \multirow{2}{*}{ Substrate } & \multirow{2}{*}{$\begin{array}{l}\text { Maximum optical } \\
\text { density at } 660 \mathrm{~nm}\end{array}$} & \multirow{2}{*}{$\begin{array}{l}\text { Amt of substrate } \\
\text { consumed (mM) }\end{array}$} & \multicolumn{2}{|c|}{ Amt of product (mM) } & \multirow{2}{*}{$\begin{array}{c}\text { Acetate/substrate } \\
\text { ratio }^{b}\end{array}$} \\
\hline & & & Acetate $^{a}$ & Protocatechuate & \\
\hline Fructose & 0.46 & 4.8 & 13.8 & $\mathrm{NA}^{c}$ & $2.88(3.0)$ \\
\hline Vanillate & 0.11 & 6.5 & 4.5 & 6.2 & $0.69(0.75)$ \\
\hline $\mathrm{H}_{2}$ & 0.08 & 23.3 & 6.6 & NA & $0.28(0.25)$ \\
\hline
\end{tabular}

a Values were corrected for the amount of acetate formed in controls lacking additional substrates.

${ }^{b}$ The values in parentheses are the theoretical ratios expected for acetogenic consumption of substrates (20).

'NA, not applicable. 


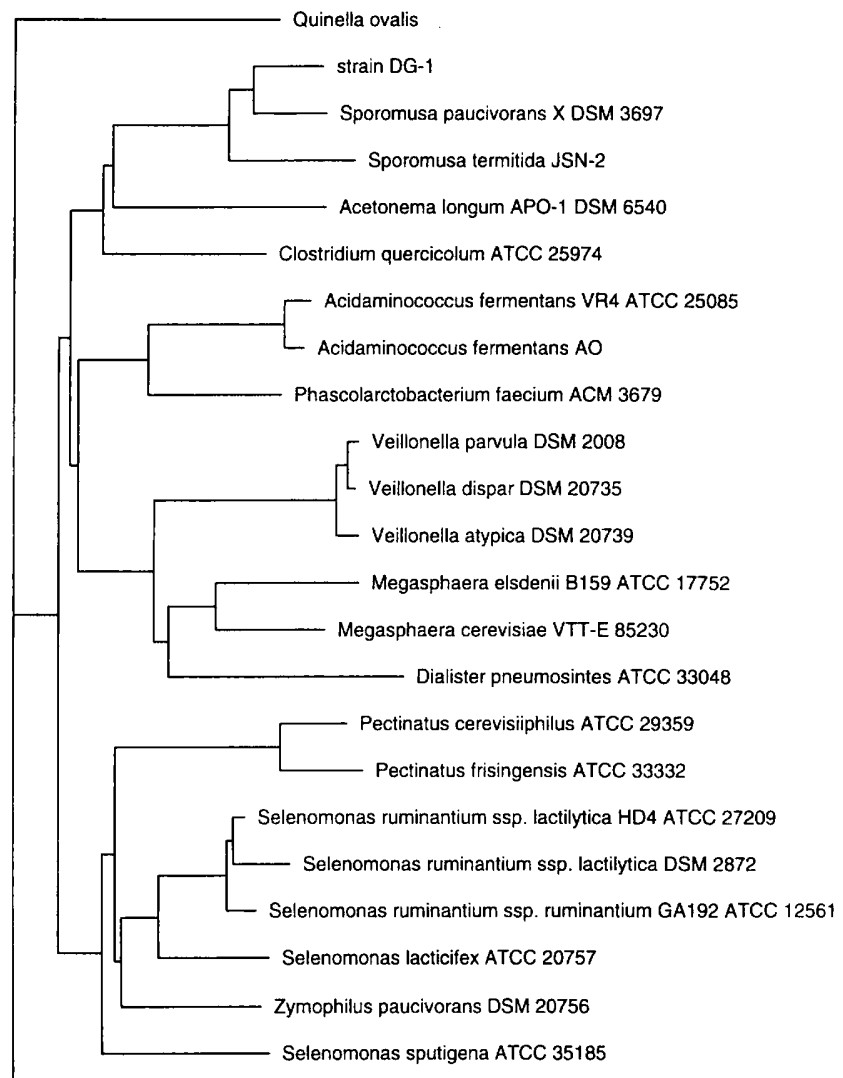

Heliobacterium chlorum ATCC 35205 0.10

FIG. 4. Dendrogram showing the phylogenetic position of strain DG-1 ${ }^{\mathrm{T}}$ (based on an analysis of $16 \mathrm{~S}$ rDNA). Scale bar $=10$ nucleotide substitutions per 100 nucleotides.

Nucleotide sequence accession number. The 16S rDNA sequence data have been deposited in the EMBL nucleotide sequence database (Cambridge, United Kingdom) under accession number Y09976.

\section{RESULTS}

Enrichment cultures. Aggregated soil was added to defined (medium B or C), soil extract, and leaf leachate media supplemented with $\mathrm{H}_{2}-\mathrm{CO}_{2}$ or vanillate-CO. $\mathrm{H}_{2}$ and $\mathrm{CO}_{2}$ were utilized, vanillate was $\mathrm{O}$-demethylated, and acetate was produced by all soil suspensions within 3 or 4 weeks; repeated transfers yielded stable acetate-producing enrichment cultures. These observations indicated that enrichment of acetogenic consortia occurred. In the leaf leachate and soil extract media, exogenous substrate utilization was retarded; however, acetate production occurred at rates similar to those observed in other media, suggesting that endogenous carbon sources were also utilized.

Isolation. Isolate $\mathrm{DG}-1^{\mathrm{T}}$ was obtained from a stable medium B enrichment culture containing $\mathrm{H}_{2}-\mathrm{CO}_{2} . \mathrm{DG}-1^{\mathrm{T}}$ produced acetate as the sole soluble end product from utilization of $\mathrm{H}_{2}$. The purity of isolate $\mathrm{DG}-1^{\mathrm{T}}$ was ensured by restreaking an isolated colony three times. Cultures of DG- $1^{\mathrm{T}}$ were considered to be pure based on uniform colony and cellular morphologies.

Morphology. Isolate DG- $1^{\mathrm{T}}$ was a strictly anaerobic, motile, rod-shaped organism. Its cells were approximately 3.5 by 0.7 $\mu \mathrm{m}$ and slightly curved (Fig. 1). Flagellar staining (4) and electron microscopy revealed laterally inserted flagella on the concave side of each cell (Fig. 1A). Cells exhibited both tumbling motility and short, directional motility in wet mounts. Although Gram staining (13) and the KOH test (28) indicated that DG $-1^{\mathrm{T}}$ was weakly gram positive, thin sections revealed a more complex, multilayer cell wall (Fig. 1B, inset). Small inclusion bodies were observed in thin sections. With fructose as the substrate, cells occasionally swelled and became teardrop shaped after growth began; terminal, spherical spores were observed in wet mounts prepared from old cultures. Free spores were rarely observed, and the capacity to sporulate appeared to decrease with prolonged laboratory cultivation. Colonies on solidified medium A supplemented with fructose were shiny, beige to slightly yellow, and 2 to $3 \mathrm{~mm}$ in diameter. The colony form was irregular with entire or slightly undulate margins.

Temperature and pH optima. Isolate DG- ${ }^{\mathrm{T}}$ grew at temperatures ranging from 10 to $35^{\circ} \mathrm{C}$ (Fig. 2A); no growth was observed at 5 or $42^{\circ} \mathrm{C}$ during incubation for 1 month. The optimal temperature was 25 to $30^{\circ} \mathrm{C}$. Growth was observed after a sporulated culture was heated for $10 \mathrm{~min}$ at $80^{\circ} \mathrm{C}$ Growth was relatively rapid when the initial $\mathrm{pH}$ was between 5.5 and 7.7 (Fig. 2B).

Doubling time. In fructose-supplemented medium $\mathrm{A}(\mathrm{pH}$ 6.8), the doubling times at 30 and $10^{\circ} \mathrm{C}$ were approximately 14 and $80 \mathrm{~h}$, respectively.

Fermentation stoichiometries. Strain DG- $1^{\mathbf{T}}$ produced acetate concomitant with growth on fructose, vanillate, or $\mathrm{H}_{2}-\mathrm{CO}_{2}$ (data not shown). The substrate-product stoichiometries obtained from such cultures indicated that acetogenic consumption of substrates occurred (Table 1). The growth yield for cells grown in medium A supplemented with $5 \mathrm{mM}$ fructose was approximately $61 \mathrm{mg}$ (dry weight) of cells liter ${ }^{-1}$, and $13.8 \mathrm{mM}$ acetate was formed, yielding an acetate/biomass ratio of 226 mmol of acetate $g$ (dry weight) of cells ${ }^{-1}$. Protocatechuate was produced in near stoichiometry with the amount of vanillate consumed, indicating that the aromatic ring was not subject to breakage or to further transformation.

Additional physiological characteristics. In medium A, growth and substrate utilization were observed with the following substrates: ferulate, vanillate, fructose, betaine, fumarate, 2,3-butanediol, pyruvate, lactate, glycerol, ethanol, methanol, formate, and $\mathrm{H}_{2}-\mathrm{CO}_{2}$. In all cases, the substrate was converted to acetate. Protocatechuate and hydroferulate were additional products observed with vanillate and ferulate, respectively. $\mathrm{H}_{2}$ and the $O$-methyl group of vanillate were utilized as cosubstrates. Fumarate was dismutated to succinate and acetate. Fumarate is also dismutated by Clostridium aceticum and Clostridium formicoaceticum $(18,41) . \mathrm{H}_{2}$ was not produced. Traces of methane were produced in addition to acetate in cultures grown with $\mathrm{H}_{2}-\mathrm{CO}_{2}$; production of trace levels of methane has also been observed with the acetogens Clostridium thermoautotrophicum (55), Acetobacterium woodil (10), and Acetobacterium carbinolicum (10).

No growth or substrate utilization was observed with cellobiose, glucose, citrate, 4-hydroxybenzaldehyde, xylose, succinate, oxalate, acetate, or $\mathrm{CO}$. According to the results of an API analysis (BioMérieux Deutschland $\mathrm{GmbH}$, Nürtingen, Germany), mannitol, lactose, saccharose, maltose, salicin, arabinose, mannose, melezitose, raffinose, sorbitol, rhamnose, and trehalose were not utilized. Additional results of the API analysis indicated that esculin was hydrolyzed, gelatin was not hydrolyzed, and tryptophanase, urease, catalase, and oxidase activities were absent. Yeast extract $\left(1 \mathrm{~g} \mathrm{liter}^{-1}\right)$ stimulated growth, but was not required. The growth rates and final cell yields were not appreciably affected when cells were cultivated 
repeatedly in sodium-deficient medium B (prepared by using potassium salts rather than sodium salts) supplemented with either fructose or $\mathrm{H}_{2}$-vanillate (data not shown).

Nitrate, rather than $\mathrm{CO}_{2}$, is the preferred terminal electron acceptor for Clostridium thermoaceticum and $C$. thermoautotrophicum and inhibits the ability of these acetogens to form acetate by repressing the electron transport system normally engaged in the acetyl coenzyme A (acetyl-CoA) pathway (21, $26,57)$. When strain DG- $1^{\mathrm{T}}$ was grown in the presence of nitrate, nitrate was not appreciably utilized and acetate production was not appreciably affected, indicating that nitrate was not used as an alternative electron acceptor by DG- $1^{\mathrm{T}}$. Sulfate was also not used as an alternative electron acceptor. Strain DG- ${ }^{\mathrm{T}}$ did not fix $\mathrm{N}_{2}$

Enzyme activities and membrane spectrum. The carbon monoxide dehydrogenase and hydrogenase activities in cell extracts were approximately 9 and $102 \mu \mathrm{mol} \mathrm{min}^{-1} \mathrm{mg}$ of protein $^{-1}$, respectively. Two electrophoretically distinct carbon monoxide dehydrogenase bands were observed on in situstained polyacrylamide gels. A type $b$ cytochrome was detected in membranes; absorption maxima were observed at 432 and $564 \mathrm{~nm}$ (Fig. 3A). The cytoplasmic fraction had absorption maxima at 431 and $561 \mathrm{~nm}$ (Fig. 3B), indicating that the cytoplasm also contained a type $b$ cytochrome or that a portion of the membranous type $b$ cytochrome was lost to the cytoplasmic fraction during membrane preparation. The chromophoric origin of the absorption maximum at $519 \mathrm{~nm}$ in the cytoplasmic fraction (Fig. 3B) was not resolved, but this absorption maximum was characteristic of the $\beta$-absorption peak of a type $c$ cytochrome.

G+C content and phylogenetic analysis of 16S rDNA. The DNA base composition of DG- $1^{\mathrm{T}}$ was $42.7 \pm 0.4 \mathrm{~mol} \% \mathrm{G}+\mathrm{C}$ $(n=6)$. Phylogenetic analysis of the 16S rDNA indicated that strain DG- $1^{\mathrm{T}}$ was most closely related to the genus Sporomusa (Fig. 4). A similarity value of $97.2 \%$ was obtained when the $16 \mathrm{~S}$ rDNA sequences of strain DG- $1^{\mathrm{T}}$ and Sporomusa paucivorans DSM $3697^{\mathrm{T}}$ were compared. A similarity value of $95.9 \%$ was obtained when the $16 \mathrm{~S}$ rDNA sequences of strain DG- $1^{\mathrm{T}}$ and Sporomusa termitida JSN-2 were compared.

\section{DISCUSSION}

Its cell shape, Gram reaction, formation of spores, and lack of sulfate reduction indicated that strain DG- $1^{\mathrm{T}}$ classically belongs to the genus Clostridium. However, thin sections revealed a multilayer cell wall characteristic of gram-negative bacteria, and the phylogenetic analysis of the 16S rDNA sequence indicated that DG- $1^{\mathrm{T}}$ is most closely related to members of the gram-negative, spore-forming genus Sporomusa in the Sporomusa subbranch of the Clostridium subphylum of the gram-positive bacteria $(40,66)$. As outlined below, the characteristics of DG- $1^{\mathrm{T}}$ are not consistent with the characteristics of previously described acetogenic strains of the genus Clostridium or the genus Sporomusa, and we propose that strain DG- $1^{\mathrm{T}}$ is a member of a new acetogenic species, $S$. silvacetica; strain DG-1 is the type strain of this new species.

The production of acetate as the primary reduced end product, the stoichiometries of acetate formation observed with fructose, vanillate, and $\mathrm{H}_{2}$ (approximately $3: 1,3: 4$, and 1:4, respectively), and carbon monoxide dehydrogenase activity indicated that strain DG-1 $1^{\mathrm{T}}$ is an acetogen. Strain DG- $1^{\mathrm{T}}$ differs from other acetogenic clostridia $(12,20,56)$ as follows: it differs from C. aceticum, Clostridium fervidus, C. formicoaceticum, Clostridium magnum, and Clostridium sp. strain CV-AA1 in its Gram reaction; it differs from $C$. fervidus, $C$. formicoaceticum, Clostridium ljungdahlii, Clostridium mayombei, Clostridium
(Oxobacter [15]) pfennigii, C. thermoaceticum, and C. thermoautotrophicum in its optimum temperature and temperature range; it differs from C. magnum in size; it differs from all other acetogenic clostridia except $C$. magnum in its cell shape during spore formation; it differs from all other acetogenic clostridia in its substrate range (i.e., it differs in specific substrates utilized on a case-by-case basis); it differs from $C$. formicoaceticum in $\mathrm{N}_{2}$ fixation (5); and it differs from all other acetogenic clostridia in its $\mathrm{G}+\mathrm{C}$ content.

The cell and spore morphologies of strain DG- $1^{\mathrm{T}}$ were typical of the genus Sporomusa (45). The following six Sporomusa species have been characterized previously: Sporomusa acidovorans (47), Sporomusa malonica (17), Sporomusa ovata (45), S. paucivorans (29), Sporomusa sphaeroides (45), and $S$. termitida (8). To date, only the $16 \mathrm{~S}$ rDNAs of $S$. paucivorans and $S$. termitida have been sequenced. In contrast to strain DG- $1^{\mathrm{T}}, S$. paucivorans does not utilize sugars, requires yeast extract for growth, has a $\mathrm{G}+\mathrm{C}$ content of $47 \mathrm{~mol} \%$, and has not been observed to form spores (29). In contrast to DG-1 ${ }^{\mathrm{T}}, S$. termitida does not utilize fructose, fumarate, or glycerol and has a $\mathrm{G}+\mathrm{C}$ content of $49 \mathrm{~mol} \%$. On a case-by-case basis, DG- $1^{\mathrm{T}}$ differs from the other Sporomusa species in spore morphology, substrate range, yeast extract requirement, and $\mathrm{G}+\mathrm{C}$ content. A type $b$ cytochrome was detected in the membranes of DG-1 ${ }^{\mathrm{T}}$, a trait characteristic of other Sporomusa species $(8$, $17,45)$. Betaine stimulates the production of membranous type $b$ cytochromes in $S$. ovata (33).

Strain DG- $1^{\mathrm{T}}$ is the first Sporomusa strain to be isolated from well-drained terrestrial soils, a habitat that is subject to fluctuations in aeration and redox potential. With the exception of S. termitida, all other Sporomusa species have been isolated from habitats that are classically considered to be anaerobic (e.g., freshwater sediments) (20). S. termitida was isolated from a termite gut (8), a microhabitat also subject to fluctuations in redox potential and anaerobiosis (9). It thus appears that certain Sporomusa species can adapt to habitats that are not strictly anaerobic. The origin of DG- $1^{\mathrm{T}}$ is also in marked contrast to the origins of numerous other mesophilic acetogens isolated from sewage, gastrointestinal tracts of animals, and water-logged habitats, such as marine sediment and ditch mud $(20,56)$.

Acetate is a major organic acid of mineral forest soils (59). Although acetate does not accumulate in situ, forest soils produce acetate and $\mathrm{CO}_{2}$ as major carbonaceous products during the turnover of endogenous organic matter in anaerobic microcosms (35). The stoichiometry of acetate production from exogenously added $\mathrm{H}_{2}$ by anaerobically incubated mineral soils $(35,63)$ suggests that acetate can be formed via the acetyl-CoA Wood-Ljungdahl pathway (20). The isolation of an acetogen from soil in Geisberg, Germany, confirms that acetogens are present and potentially active in anaerobic microsites in aggregated forest soils.

The degradation of lignocellulose yields lignin monomers, such as vanillate, syringate, and ferulate $(14,25)$. Strain DG- $1^{\mathrm{T}}$ exhibited a broad substrate range and utilized methoxylated lignin derivatives in addition to sugars, alcohols, organic acids, betaine, and $\mathrm{H}_{2}-\mathrm{CO}_{2}$. In contrast to $C$. aceticum and $C$. formicoaceticum (27), strain DG-1 ${ }^{\mathrm{T}}$ did not grow at the expense of 4-hydroxybenzaldehyde. A number of acetogens can utilize multiple substrates simultaneously $(7,38,41)$. In addition, most acetogens can utilize electron acceptors other than $\mathrm{CO}_{2}$ for the conservation of energy $(20,21,56)$. Strain DG- $1^{\mathrm{T}}$ used $\mathrm{H}_{2}$ and the methoxyl groups of vanillate as cosubstrates, a metabolic capacity that may enhance the in situ activities of certain acetogens (38). Strain DG- $1^{\mathrm{T}}$ did not engage in lactate fermentation concomitant with acetogenesis, as Peptostrepto- 
coccus productus U-1 can (44), but did exhibit the ability to utilize aromatic acrylate groups as electron acceptors, as certain other acetogens, such as $A$. woodii $(2,61)$ and $P$. productus U-1 (43), do. In addition, fumarate was dismutated to succinate and acetate, suggesting that reduction of fumarate to succinate may be an energy-conserving process, as is the case in C. aceticum and $C$. formicoaceticum $(18,41)$. The capacity of other Sporomusa species to utilize fumarate and aromatic acrylate groups as terminal electron acceptors has not been reported previously $(8,17,29,45,47)$. The broad substrate, $\mathrm{pH}$, and temperature ranges of strain DG- $1^{\mathrm{T}}$ may contribute to its competitiveness in a soil-based ecosystem subject to large environmental changes and limited substrate availability.

It has been proposed that acetate forms a trophic link between anaerobic and aerobic processes in certain soils $(21,35$, $63)$. This hypothesis is based on the observation that acetate is a stable end product under experimentally imposed anaerobic conditions and is converted to methane only after extensive lag periods (approximately 1 to 3 months) at in situ temperatures. In the presence of oxygen, however, anaerobically produced acetate is readily oxidized to $\mathrm{CO}_{2}(21,35,63)$. The anaerobic and acetogenic capacities of aggregated soils are relatively stable during periods of $\mathrm{O}_{2}$ enrichment and aerobic drying (63); oxic leaf litter also has acetogenic capacities (36). Spore formation may allow strain DG-1 ${ }^{\mathrm{T}}$ and other soil-dwelling anaerobes involved in acetate production to compete in an environment where redox conditions are constantly changing.

Description of Sporomusa silvacetica sp. nov. Sporomusa silvacetica (sil.va.ce'ti.cum. L. n. silva, forest; L. fem. adj. acetica, pertaining to vinegar, acetic acid; N. L. fem. adj. silvacetica, a forest organism producing acetic acid). Based on 16S rDNA analysis data, strain DG $-1^{\mathrm{T}}$ is most closely related to the genus Sporomusa in the Clostridium subphylum of the gram-positive bacteria.

Cells are weakly gram-positive, motile rods that are slightly curved (approximately 3.5 by $0.7 \mu \mathrm{m}$ ), occur singly or in pairs, and form round, terminal spores. The cell wall is multilayered, and flagella are laterally inserted on the concave side of each cell. Colonies growing on fructose are shiny, beige to slightly yellow, and 2 to $3 \mathrm{~mm}$ in diameter. Obligate anaerobe. The optimum temperature and optimum $\mathrm{pH}$ for growth are 25 to $30^{\circ} \mathrm{C}$ and 6.8 , respectively; under these conditions and with fructose as the substrate, the doubling time is $14 \mathrm{~h}$.

Uses the acetyl-CoA pathway for acetate synthesis. Grows with ferulate, vanillate, fructose, fumarate, betaine, 2,3-butanediol, pyruvate, lactate, glycerol, ethanol, methanol, formate, and $\mathrm{H}_{2}-\mathrm{CO}_{2}$. Reduces fumarate and the aromatic acrylate group of ferulate. Does not require yeast extract for growth. Does not grow by dissimilation of nitrate or sulfate. Nitrogen is not fixed. Catalase and oxidase negative. Contains a membranous type $b$ cytochrome. The $\mathrm{G}+\mathrm{C}$ content of the DNA is approximately $43 \mathrm{~mol} \%$.

The type strain, strain DG-1, was isolated from the mineral horizon of a beech forest soil in Bavaria, Germany, and has been deposited in the Deutsche Sammlung von Mikroorganismen und Zellkulturen as strain DSMZ 10669.

\section{ACKNOWLEDGMENTS}

We are indebted to $\mathrm{W}$. Whitman for the $\mathrm{G}+\mathrm{C}$ analysis and to $\mathrm{S}$. Daniel, K. Küsel, S. Braus-Sromeyer, and C. Matthies for helpful discussions and critical reviews of the manuscript.

Support for this study was provided by German Ministry for Education, Research, and Technology grant 0339476AO and European Commission grant EV5V-CT92-0143.

\section{REFERENCES}

1. Alef, K. 1991. Methodenhandbuch Bodenmikrobiologie. Ecomed Verlagsgesellschaft mbh, Landsberg/Lech, Germany.

2. Bache, R., and N. Pfennig. 1981. Selective isolation of Acetobacterium woodi on methoxylated aromatic acids and determination of growth yields. Arch Mikrobiol. 72:154-174.

3. Beji, A., D. Izard, F. Gavini, H. Leclerc, M. Leseine-Delstanche, and J. Krembel. 1987. A rapid chemical procedure for isolation and purification of chromosomal DNA from Gram-negative bacilli. Anal. Biochem. 162:18-23.

4. Blenden, D. C., and H. S. Goldberg. 1965. Silver impregnation stain for Leptospira and flagella. J. Bacteriol. 89:899-900.

5. Bogdahn, M., J. R. Andreesen, and D. Kleiner. 1983. Pathways and regulation of $\mathrm{N}_{2}$, ammonium and glutamate assimilation by Clostridium formicoaceticum. Arch. Microbiol. 134:167-169.

6. Bradford, M. M. 1976. A rapid and sensitive method for the quantitation of microgram quantities of protein utilizing the principle of protein-dye binding. Anal. Biochem. 72:248-254.

7. Breznak, J. A. 1994. Acetogenesis from carbon dioxide in termite guts, p. 303-330. In H. L. Drake (ed.), Acetogenesis. Chapman \& Hall, New York, N.Y

8. Breznak, J. A., J. M. Switzer, and H.-J. Seitz. 1988. Sporomusa termitida $\mathrm{sp}$ nov., an $\mathrm{H}_{2} / \mathrm{CO}_{2}$-utilizing acetogen isolated from termites. Arch. Microbiol. 150:282-288

9. Brune, A., D. Emerson, and J. A. Breznak. 1995. The termite gut microflora as an oxygen sink: microelectrode determination of oxygen and $\mathrm{pH}$ gradients in guts of lower and higher termites. Appl. Environ. Microbiol. 61:26812687.

10. Buschhorn, H., P. Dürre, and G. Gottschalk. 1989. Production and utilization of ethanol by the homoacetogen Acetobacterium woodii. Appl. Environ. Microbiol. 55:1835-1840.

11. Cataldo, D. A., M. Haroon, L. E. Schrader, and V. L. Young. 1975. Rapid colorimetric determination of nitrate in plant tissue by titration of salicylic acid. Commun. Soil Sci. Plant Anal. 6:81-90.

12. Cato, E. P., W. L. George, and S. M. Finegold. 1986. Clostridium, p. 11411200. In P. H. A. Sneath, N. S. Mair, M. E. Sharpe, and J. G. Holt (ed.) Bergey's manual of systematic bacteriology, vol. 2. Williams \& Wilkins, Baltimore, Md

13. Clark, G. 1973. Staining procedures used by the Biological Stain Commission, 3rd ed. The Williams \& Wilkins Co., Baltimore, Md.

14. Colberg, P. J. 1988. Anaerobic microbial degradation of cellulose, lignin, oligolignols, and monoaromatic lignin derivatives, p. 333-372. In A. J. B. Zehnder (ed.), Biology of anaerobic microorganisms. Wiley, New York, N.Y

15. Collins, M. D., P. A. Lawson, A. Willems, J. J. Cordoba, J. FernandezGarayzabal, P. Garcia, J. Cai, H. Hippe, and J. A. E. Farrow. 1994. The phylogeny of the genus Clostridium: proposal of five new genera and eleven new species combinations. Int. J. Syst. Bacteriol. 44:812-826.

16. Daniel, S. L., T. Hsu, S. I. Dean, and H. L. Drake. 1990. Characterization of the $\mathrm{H}_{2}-$ and $\mathrm{CO}$-dependent chemolithotrophic potentials of the acetogens Clostridium thermoaceticum and Acetogenium kivuii. J. Bacteriol. 172:4464 4471

17. Dehning, I., M. Stieb, and B. Schink. 1989. Sporomusa malonica sp. nov., a homoacetogenic bacterium growing by decarboxylation of malonate and succinate. Arch. Microbiol. 151:421-426.

18. Dorn, M., J. R. Andreesen, and G. Gottschalk. 1978. Fermentation of fumarate and L-malate by Clostridium formicoaceticum. J. Bacteriol. 133:26-32.

19. Drake, H. L. 1982. Demonstration of hydrogenase in extracts of the homoacetate-fermenting bacterium Clostridium thermoaceticum. J. Bacteriol. 150: 702-709.

20. Drake, H. L. 1994. Acetogenesis, acetogenic bacteria, and the acetyl-CoA "Wood/Ljungdahl" pathway: past and current perspectives, p. 3-60. In H. L. Drake (ed.), Acetogenesis. Chapman \& Hall, New York, N.Y.

21. Drake, H. L., S. L. Daniel, K. Küsel, C. Matthies, C. Kuhner, and S. Braus-Stromeyer. Acetogenic bacteria: what are the in situ consequences of their diverse metabolic versatilities? BioFactors, in press

22. Felsenstein, J. 1993. PHYLIP (phylogeny inference package), version 3.5.1. Department of Genetics, University of Washington, Seattle.

23. Flaig, W. 1971. Organic compounds in soil Soil Sci. 111:19-33.

24. Fox, T. R., and N. B. Comerford. 1990. Low-molecular-weight organic acids in selected forest soils of the southeastern USA. Soil Sci. Soc. Am. J. 54 $1139-1144$.

25. Frazier, A. C. 1994. O-Demethylation and other transformations of aromatic compounds by acetogenic bacteria, p. 445-483. In H. L. Drake (ed.), Acetogenesis. Chapman \& Hall, New York, N.Y.

26. Fröstl, J. M., C. Seifritz, and H. L. Drake. 1996. Effect of nitrate on the autotrophic metabolism of the acetogens Clostridium thermoautotrophicum and Clostridium thermoaceticum. J. Bacteriol. 178:4597-4603.

27. Gößner, A., S. L. Daniel, and H. L. Drake. 1994. Acetogenesis coupled to the oxidation of aromatic aldehyde groups. Arch. Microbiol. 161:126-141.

28. Gregersen, T. 1978. Rapid method for distinction of Gram-negative from Gram-positive bacteria. Eur. J. Appl. Microbiol. Biotechnol. 5:123-127.

29. Hermann, M., M.-R. Popoff, and M. Sebald. 1987. Sporomusa paucivoran sp. nov., a methylotrophic bacterium that forms acetic acid from hydrogen 
and carbon dioxide. Int. J. Syst. Bacteriol. 37:93-101.

30. Huang, P. M., and A. Violante. 1986. Influence of organic acids on crystallization and surface properties of precipitation products of aluminum, $p$ 159-221. In P. M. Huang and M. Schnitzer (ed.), Interactions of soil minerals with natural organics and microbes. Soil Science Society of America, Inc., Madison, Wis.

31. Hungate, R. E. 1969. A roll tube method for cultivation of strict anaerobes. Methods Microbiol. 3B:117-132.

32. Jukes, T. H., and C. R. Cantor. 1969. Evolution of protein molecules, p. 21-132. In H. N. Munro (ed.), Mammalian protein metabolism. Academic Press, New York, N.Y.

33. Kamlage, B., A. Boelter, and M. Blaut. 1993. Spectroscopic and potentiometric characterization of cytochromes in two Sporomusa species and their expression during growth on selected substrates. Arch. Microbiol. 159:189196.

34. Küsel, K., and H. L. Drake. 1994. Acetate synthesis by soil from a Bavarian beech forest. Appl. Environ. Microbiol. 60:1370-1373.

35. Küsel, K., and H. L. Drake. 1995. Effects of environmental parameters on the formation and turnover of acetate by forest soils. Appl. Environ. Microbiol. 61:3667-3675.

36. Küsel, K., and H. L. Drake. 1996. Anaerobic capacities of leaf litter. Appl Environ. Microbiol. 62:4216-4219.

37. Limmer, C., and H. L. Drake. 1996. Non-symbiotic $\mathrm{N}_{2}$-fixation in acidic and $\mathrm{pH}$-neutral forest soils: aerobic and anaerobic differentials. Soil Biol. Biochem. 28:177-183.

38. Liu, S., and J. M. Suflita. 1993. $\mathrm{H}_{2}-\mathrm{CO}_{2}$-dependent anaerobic O-demethylation activity in subsurface sediments and by an isolated bacterium. Appl. Environ. Microbiol. 59:1325-1331.

39. Lundie, L. L., Jr., and H. L. Drake. 1984. Development of a minimally defined medium for the acetogen Clostridium thermoaceticum. J. Bacteriol 159:700-703.

40. Maidak, B. L. G. J. Olsen, N. Larsen, M. J. McCaughey, and C. R. Woese, 1996. The Ribosomal Database Project (RDP). Nucleic Acids Res. 24:82-85.

41. Matthies, C., A. Freiberger, and H. L. Drake. 1993. Fumarate dissimilation and differential reductant flow by Clostridium formicoaceticum and Clostridium aceticum. Arch. Microbiol. 160:273-278.

42. Mesbah, M., U. Premachandran, and W. B. Whitman. 1989. Precise measurement of the $\mathrm{G}+\mathrm{C}$ content of deoxyribonucleic acid by high-performance liquid chromatography. Int. J. Syst. Bacteriol. 39:159-167.

43. Misoph, M., S. L. Daniel, and H. L. Drake. 1996. Bidirectional usage of ferulate by the acetogen Peptostreptococcus productus U-1: $\mathrm{CO}_{2}$ and aromatic acrylate groups as competing electron acceptors. Microbiology 142: 1983-1988.

44. Misoph, M., and H. L. Drake. 1996. Effect of $\mathrm{CO}_{2}$ on the fermentation capacities of the acetogen Peptostreptococcus productus U-1. J. Bacteriol. 178:3140-3145

45. Möller, B., R. Oßmer, B. H. Howard, G. Gottschalk, and H. Hippe. 1984 Sporomusa, a new genus of gram-negative anaerobic bacteria including Sporomusa sphaeroides spec. nov. and Sporomusa ovata spec. nov. Arch. Microbiol. 139:388-396.

46. Nozhevnikova, A. N., O. R. Kotsyurbenko, and M. V. Simankova. 1995 Acetogenesis at low temperature, p. 416-431. In H. L. Drake (ed.), Acetogenesis. Chapman \& Hall, New York, N.Y.

47. Ollivier, B., R. Cordruwisch, A. Lombardo, and J.-L. Garcia. 1985. Isolation and characterization of Sporomusa acidovorans sp. nov., a methylotrophic homoacetogenic bacterium. Arch. Microbiol. 142:307-310.

48. Peters, V., and R. Conrad. 1995. Methanogenic and other strictly anaerobic bacteria in desert soil and other oxic soils. Appl. Environ. Microbiol. 61: $1673-1676$

49. Pohlmann, A. A., and J. G. McColl. 1988. Soluble organics from forest litter and their role in metal dissolution. Soil. Sci. Soc. Am. J. 52:265-271.

50. Postgate, J. R. 1984. The sulphate-reducing bacteria, 2nd ed. Cambridge University Press, London, England.

51. Rainey, F. A., N. Ward-Rainey, R. M. Kroppenstedt, and E. Stackebrandt. 1996. The genus Nocardiopsis represents a phylogenetically coherent taxon and a distinct actinomycete lineage; proposal of Nocardiopsaceae fam. nov. Int. J. Syst. Bacteriol. 46:1088-1092.

52. Rennie, R. 1981. A single medium for the isolation of acetylene-reducing (dinitrogen-fixing) bacteria from soils. Can. J. Microbiol. 27:8-14.

53. Reynolds, E. S. 1963 . The use of lead citrate at high $\mathrm{pH}$ as an electron opaque stain in electron microscopy. J. Cell Biol. 7:208.

54. Saitou, N., and M. Nei. 1987. The neighbor-joining method: a new method for reconstructing phylogenetic trees. Mol. Biol. Evol. 4:406-425.

55. Savage, M. D., Z. Wu, S. L. Daniel, L. L. Lundie, Jr., and H. L. Drake. 1987 Carbon monoxide-dependent chemolithotrophic growth of Clostridium thermoautotrophicum. Appl. Environ. Microbiol. 53:1902-1906.

56. Schink, B. 1994. Diversity, ecology and isolation of acetogenic bacteria, p. 197-235. In H. L. Drake (ed.), Acetogenesis. Chapman \& Hall, New York, N.Y.

57. Seifritz, C., S. L. Daniel, A. Gößner, and H. L. Drake. 1993. Nitrate as a preferred electron sink for the acetogen Clostridium thermoaceticum. J. Bacteriol. 175:8008-8013.

58. Stevenson, F. J. 1967. Organic acids in soil, p. 119-146. In A. D. McLaren and G. H. Peterson (ed.), Soil biochemistry, vol. 1. Marcel Dekker, New York, N.Y.

59. Tani, M., T. Higashi, and S. Nagatsuka. 1993. Dynamics of low-molecularweight aliphatic carboxylic acids (LACAs) in forest soils. I. Amount and composition of LACAs in different types of forest soils in Japan. Soil. Sci. Plant Nutr. 39:485-495.

60. Traub, W. H., G. Acker, and I. Kleber. 1976. Ultrastructural surface alterations of Serratia marcescens after exposure to polymyxin B and/or fresh human serum. Chemotherapy 22:104-113.

61. Tschech, A., and N. Pfennig. 1984. Growth yield increase linked to caffeate reduction in Acetobacterium woodii. Arch. Mikrobiol. 72:154-174.

62. Valentine, R. C., B. M. Shapiro, and E. R. Stadtman. 1968. Regulation of glutamine synthetase. XII. Electron microscopy of the enzyme from Escherichia coli. Biochemistry 7:2143-2152.

63. Wagner, C., A. Grießhammer, and H. L. Drake. 1996. Acetogenic capacities and the anaerobic turnover of carbon in a Kansas prairie soil. Appl. Environ. Microbiol. 62:494-500.

64. Widdel, F., G. W. Kohring, and F. Mayer. 1983. Studies on dissimilatory sulfate-reducing bacteria that decompose fatty acids. III. Characterization of the filamentous gliding Desulfonema limicola gen. nov., sp. nov., and Desulfonema magnum sp. nov. Arch. Microbiol. 134:286-294.

65. Widdel, F., and N. Pfennig. 1981. Studies on dissimilatory sulfate-reducing bacteria that decompose fatty acids. I. Isolation of new sulfate-reducing bacteria enriched with acetate from saline environments. Description of Desulfobacter postgatei gen. nov., sp. nov. Arch. Microbiol. 129:395-400.

66. Willems, A., and M. D. Collins. 1995. Phylogenetic placement of Dialister pneumosintes (formerly Bacteriodes pneumosintes) within the Sporomusa subbranch of the Clostridium subphylum of the gram-positive bacteria. Int. J. Syst. Bacteriol. 45:403-405.

67. Wolin, E. A., R. S. Wolfe, and M. J. Wolin. 1964. Viologen dye inhibition of methane formation by Methanobacillus omelianskii. J. Bacteriol. 87:993-998 